\title{
TULIP TIME IN ORANGE CITY: A BRIEF HISTORY
}

\section{By Arie Vander Stoep}

The following article is a section of a detailed study by Mr. Arie Vander Stoep, Orange City, concerning the Orange City Tulip Festival.

Orange City is one of three predominently Dutch communities in the United States to sponsor a Tulip Festival, the others being Pella, Iowa, and Holland, Mich. All three of these cities boast a college, sponsored by the Reformed Church in America, and the ties between the cities, especially Orange City and Pella, are numerous.

The first Dutch families to settle in the vicinity of Orange City, Sioux County, left Pella in the Spring of 1870 for "new land." Their party, led by Hendrik Jan Van Der Waa, was small, consisting of five wagons, and the way was rough, but the beauty of the land awaiting them was ample reward for their trip. After the first wagon train left Pella, a much larger train was formed and many more "Pella" Dutch, led by Leendert Van Der Meer and Dirk Van Den Bos, left for the "land of promise" in northwestern lowa. So started the birth and growth of this community which, proud of its heritage and tradition, sponsors an annual three-day Tulip Festival, a festival of the beauty of nature, of bright colors and of gaicty.

A Tulip Festival History must start somewhere. If one would question a score of Orange City's older citizens as to the date of the beginning of the Orange City Tulip Festival, as many different answers would be received. Most of the answers would be guesses, some of them well considered opinions, and others would be based on a philosophy of cause and effect.

The aberrant opinion would relegate the beginning to the period in European History when the tulip bulb became an item of wild market speculation through parts of the 16th and 17th centuries. There is no doubt that at that time the tulip 
as a flower developed the popularity which it has enjoyed ever since. It would, however, be presumptuous to attribute the embryonic stage of the present Orange City Tulip Festival to such historic economic unbalance.

Considerable recognition must be given the opinions that festival seeds were definitely sown in 1933. According to an account in the Orange City Journal of May 4, 1933, the first Annual Tulip Show was sponsored by the joint efforts of the Lion's Club, Yard and Garden Club and the Women's Club. Tulips were individually judged in their beds before they were cut. No tulip was cut before it was judged a prize winner. After all beds had been scrutinized, the prize-winning blooms were cut and various bouquets were arranged for display.

Encouraged by the interest in this first Tulip Show, enthusiasts enlarged upon it in 1934 and using the organized efforts of the Orange City Chamber of Commerce, the first special tulip plantings were made in 1935 . The next year, 1936, marks the beginnings of the now Internationally publicized Tulip Festival, first referred to as the May Festival. Pertinent details of this festival have been related elsewhere in this chronicle.

In order to avoid monotonous and meaningless repetition of the conventional and traditional phases of the Festival, the standard and the established events comprising the warp and woof of all the Festivals are here reviewed in one scope. A typical printed program for any year would contain the following outline of activities:

Each morning-

Dutch Antique Museum at City Auditorium.

Tulip Exhibits-all tulip gardens open to visitors.

1:30 P.M.-Dutch Street Program

Street Inspection.

Street Scrubbing.

Parade of decorative floats and marching bands.

Festival Queen's Coronation.

Street Dancers-100 girls in Costume and Klompen.

7:00 P.M.

Parade of Floats and Marching Bands.

Dutch Street Dancers.

8:15 P.M.

Local Talent Production, City Auditorium.

Presentation of Tulip Queen and Attendants. 
A lengthy composition describing the origin and nature of each of these events would not be amiss, but justice could not be done to such an undertaking in the alloted scope of this assignment.

\section{Synopsis of 25 Years of Community Effort}

Records of events leading up to Orange City's first Tulip Festival are rather meager and indefinite. The Hollanders' innate tendency toward cleanliness and beauty combined with an historical background of flower culture is an acceptable although abstract motivating force. This force found physical expression as early as 1935 when it was recorded that in addition to the large number of tulip plantings already in existence in Orange City, some 50,000 more bulbs were imported and planted by the townspeople.

It would be presumptuous to single out any one or two individuals whose special efforts were instrumental in establishing the institution now referred to as The Tulip Festival, and except in clear-cut cases, references to individuals are better avoided in order to eliminate disputes. It can safely be said, however, that Edward Bolluyt and the late O. N. Ross were strong motivating personalities of the project.

Using the organized efforts of the Orange City Chamber of Commerce, the first Special tulip plantings were made in 1935, and the next year marks the beginning of the now much publicized Tulip Festival, first referred to as the May Festival.

Accounts of activities in the April and May 1936 issues of the Sioux County Capital, indicate that the first festival, May 14, featured a parade, costume contest, LeMars Drum and Bugle Corps, Better Homes and Gardens photographers staff, the Friesian Society Sing, window displays of Holland momentos, American Legion Concessions, Northwestern Junior College Chorus and Orange City High School Band, and in the evening, a concert by the Sioux City Symphony Orchestra.

The outstanding innovation of the 1937 festival was the election and coronation of the first Tulip Queen, Elizabeth Top (Swets). The next year an elaborate and formal coronation ceremony was introduced into the program, involving not only the Queen and her attendants but a score or more of additional personnel as guards, ushers, trumpeters, etc. Cere- 
monial functions have, throughout the 25 years, been carried out by City Officials and Iowa's Vice Council for the Netherlands, also a local citizen. With minor changes this ceremony is still considered one of the most colorful and impressive attractions of the Festival.



Dutch street cleaners.

Because of the public interest in the Tulip Festival and the consequential large crowds attending, 1938 marked the first year of two day festivities. The entire program of activities was repeated each day and on each evening, "In Dutch," a musical comedy in two acts, locally composed and cast, was put on at the City Auditorium.

During the next three years, 1939, 1940 and 1941, the general trend of festivities followed the established pattern, and interest in the Festival grew in unexpected proportions. Each year thousands of additional tulip bulbs were imported and substantial gifts of bulbs were received from the Netherlands Bulb Growers Association.

The war years followed and from 1942 through 1946 festivities were replaced by Victory Days and other appropriate observance events. In the Fall of 1946, 50,000 new bulbs were imported and planted in anticipation of the 1947 Festival.

During the next three years the renewed interest and enthusiasm was so wide spread that in 1950 the Tulip Festival Steering Committee found it both necessary and desirable to institute a three day Festival. Requests representing thousands of interested folks from cities such as Sioux Falls and Sioux City, unable to attend except on Saturdays, and from schools 
on behalf of teachers and pupils alike, were strong inducements for the now established three day Festival including a Saturday.

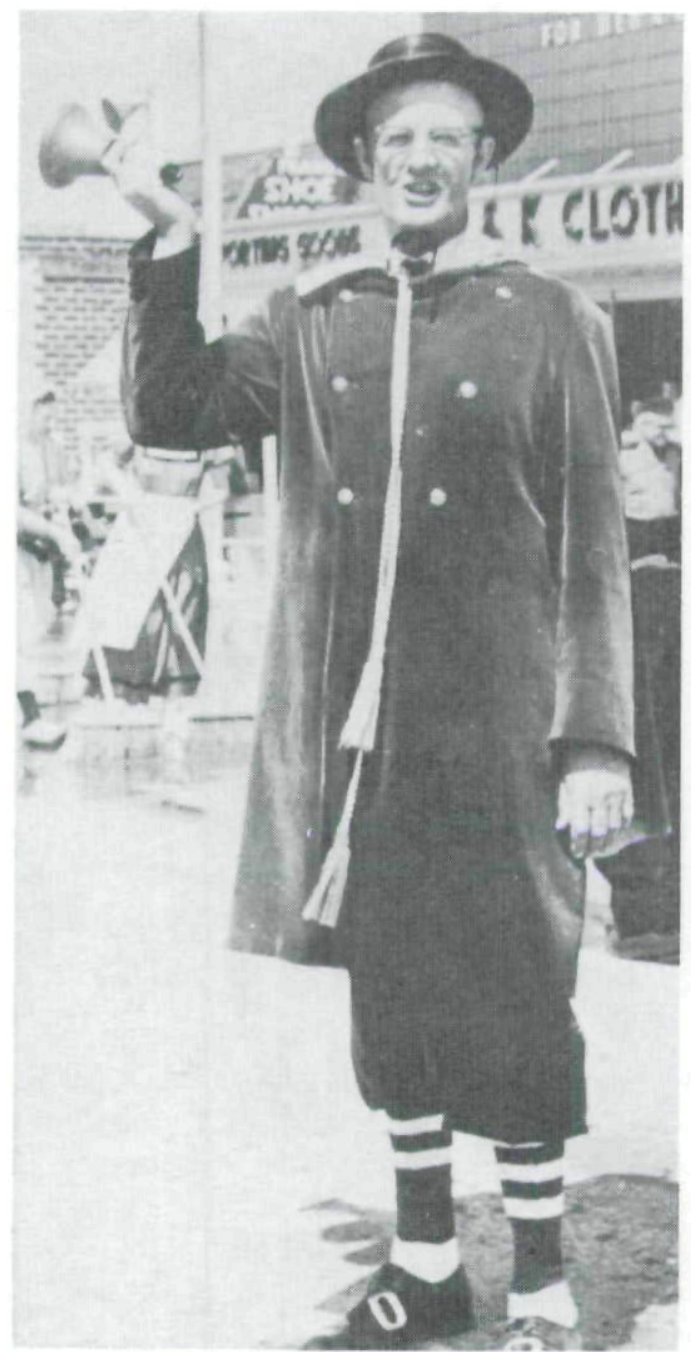

The Orange City Town Crier Gerald Kalsbeck. 
1950 was one of the climatic years because of the attendance, as special guest, of His Excellency E. N. Van Kleffen, Netherlands' Ambassador to the United States. This momentuous event in addition to the three day Festival, made total attendance soar to new heights. The evening show marked the revival of a home talent production "Tulip Time Musical" which included the operetta "Tulip Time in Holland."

The year 1951 marked the beginning of a new era in Home Talent production of the evening show. Victor Herbert's "The Red Mill" was a complete sell-out, with hundreds of admission requests turned down. "The Red Mill" was repeated in 1952 with even more enthusiastic response. In 1953 the committee felt that a change might be acceptable and Victor Herbert's "Sweethearts" was presented to overflow crowds for four evenings. In 1954 and 1955 these two productions were again presented alternately with local color innovations and with continued enthusiastic reception by the public. In 1956 the committee in charge felt that the home talent personnel had earned a season of relaxation, and succeeded in booking the nationally famous Male Quartet known to radio and television as "The Mariners."

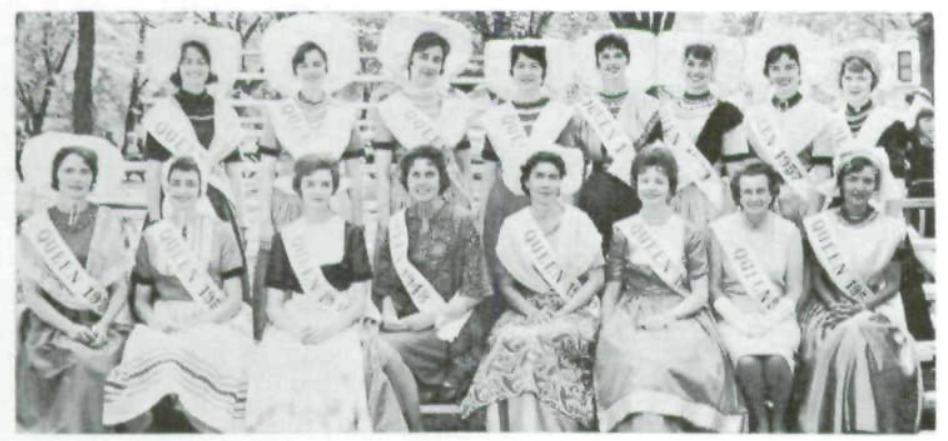

Tulip Queens-Back: Judy Raak, '64, Jean Miller, '63, Mrs. Lou Massman, '62, Karen Bogaard, '61, Mrs. Don Vander Wel, '60, Mrs. Fred Scholten, '59, Mrs. Wallace Broenweg, '57, Mrs. Dell Arenson, '56; Front: Mrs. Dave Duistermars, '51, Mrs. Harris Van Oort, '50, Mrs. Gerald Reinders, '49, Mrs. Dean Hull, '48, Mrs. Randall Van Gelder, '40, Mrs. Calvin Groen, '39, Mrs. Elizabeth Swets, '37, Mrs. Adrian De Haan, '53. 
The next six years were highlighted by the advent of a professional Wooden Shoe maker from the Netherlands; the attendance of Miss Joyce Rice of Greenville, Iowa, National Baton Twirling Champion; the Premiere showing of "The Willow Man," and a completely new method of selecting the Tulip Queen by a panel of judges assisted by the public.

Although the general program since 1947 has followed a definite pattern, those who serve on the many committees are particularly aware of the myriads of changes, additions and refinements appearing each year. These unnoticed developments produce the "overtones" which keep this annual Festival ever new.

\section{Tulip History and Culture}

With tulips always the center of interest and a stimulant for intense activities on the part of Orange Citians conjectures as to the origin and devolpment of this star performer are many and varied, all with some vestige of authenticity, but few, and justly so, with factual background.

Limited research reveals, that although the bulb was being cultivated in Turkey by the middle of the 16th century, its ancestry was intraceable before that time. On Sept. 1, 1555, O. B. Busbecq, then ambassador from Vienna to the Ottoman Empire, mentions "Tulipans" in a letter to a friend. According to Leo A. Borah's review of "Some Odd Papers from Annals of the Tulip," Busbecq receives credit for the introduction of the tulip in Europe. His letter to a friend, it is observed, "Was the first written mention in Europe of the flower destined within a century to create mania among gardners of half the continent-and to turn the heads of the ordinarily placid Dutch, and to become the innocent cause of a wild speculation in the Netherlands."

Busbecq not only introduced it to Europe, but gave it a wrong name. The Turks had only one title for the plant"lale," also used by the Persians and the Arabs. It is assumed that an interpreter referred to the Turkish head dress, the "Tulband" with the actual name, and transliterated the wrong word into Latin, which it has carried as its name through the centuries. 
Many interesting references are cited by M. Borah relative to the tulip's introduction to England, Belgium and Holland. The flowers became popular immediately, probably because of their amazing varied colors and their tendency to unexpected hues, and the botanical phenomenon of "breaking"-producing varied colors, striped, spotted or mottled blossoms-most frequently observed in plants that had been flowering for several years. By the beginning of the 17th century the species growing in Holland, France, Germany and Flanders were almost countless. References have been disclosed of 1323 varieties, describing 74 in detail.

The avid demands for tulips in Europe brought prices to high levels and it is noted that a single bulb which might have caught the fancy of a French Nobleman would be sold for "Hundreds of Florins."

When France became incessantly involved in her wars, the center of the Tulip culture moved to Holland, particularly about Harlem and Leiden. Soils of the lowland countries were found ideal for growing the plants. History refers to the "Tulip Monia" in Holland of the early 17th century and more has been written about it than its importance warrants. Huge sums were gambled on the possible futures and variety of production of newly planted beds.

Mr. Borah remarked "Queer bargains were made," and an example that reems particularly ridiculous being the exchange of one bulb for a load of grain, four fat oxen, twelve sheeps, five pigs, two barrels of butter, one thousand pounds of cheese, four barrels of beer, two hogsheads of wine, a bed stead with its furnishings, a suit of clothes and a silver drinking cup.

Real tulip fanciers were shouldered out of the bidding by professional market operators. With nothing of real value to support the trade, the mania rose to absurd intensity. Public gambling ran riot and soon the government was forced to stop the speculation. This brought on the "bust" and liquidation was inevitable. However, the real tulip fanciers "tended their gardens," the business again became stabilized, and revived under stable regulations.

Subsequent research revealed that the "breaking" phenomenon which caused the variations of the bloom was a 
result of a virus disease, and with a few exceptions the healthy tulip remains a "solid" color.

\section{Tulip Culture in Orange City}

Tulip culture in Orange City and similarly located communities meet with many natural adversities. In general, the North Temperate Zone is suitable. Locations where bulbs are developed are ordinarily shore bound. Reference is made to the Puget Sound country of Washington, some New England states and much of the state of Michigan.

Where bulbs are raised on a commercial basis, necessary labor and cost of soil preparation are of course, justifiable. For the individual tulip fancier and gardener, the economics of a good Tulip showing dictates the periodical purchase of well developed bulbs.

For good flower display under local conditions, bulbs should be planted eight to ten inches deep, in light, welldrained soil. Plantings can be made anytime the dealers offer bulbs for sale, and before the ground is frozen over. Mulching should be applied but not before the ground is frozen over, and removed in the spring as the sprouts peep through.

If the same ground is to be used in successive years with new bulbs planted each year the bulbs should be dug up immediately after the blooming period, for the longer they stay in the ground, the smaller will be the chances of producing good flowers in the same location the next year. If home grown bulbs are to be planted in the same ground for several years, best results are obtained by removing the faded flowers close to the top of the stem and before the seed pods are formed. The foliage should be encouraged to remain green as long as possible, for during the growing period after the flowering, the new bulbs are being formed for the next year.

When the foliage is completely withered, the new bulbs can be lifted. These should be stored in a dry and airy space and after a few weeks can be sorted and planted. A bulb measuring one inch or more in diameter will likely provide a flower the next season.

Gardeners would remember that cultural conditions in the average garden do not compare with those found in commercial bulb growing fields, thus second year bulbs will not be likely to give as good results as new bulbs. 


\section{The Dutch Street Organ}

The acquisition of the Dutch Street Organ, a priceless relic, was not one of those things that "just happened." The contributing circumstances and facts surrounding the project are precisely recorded in the "Festival Scrap Books."

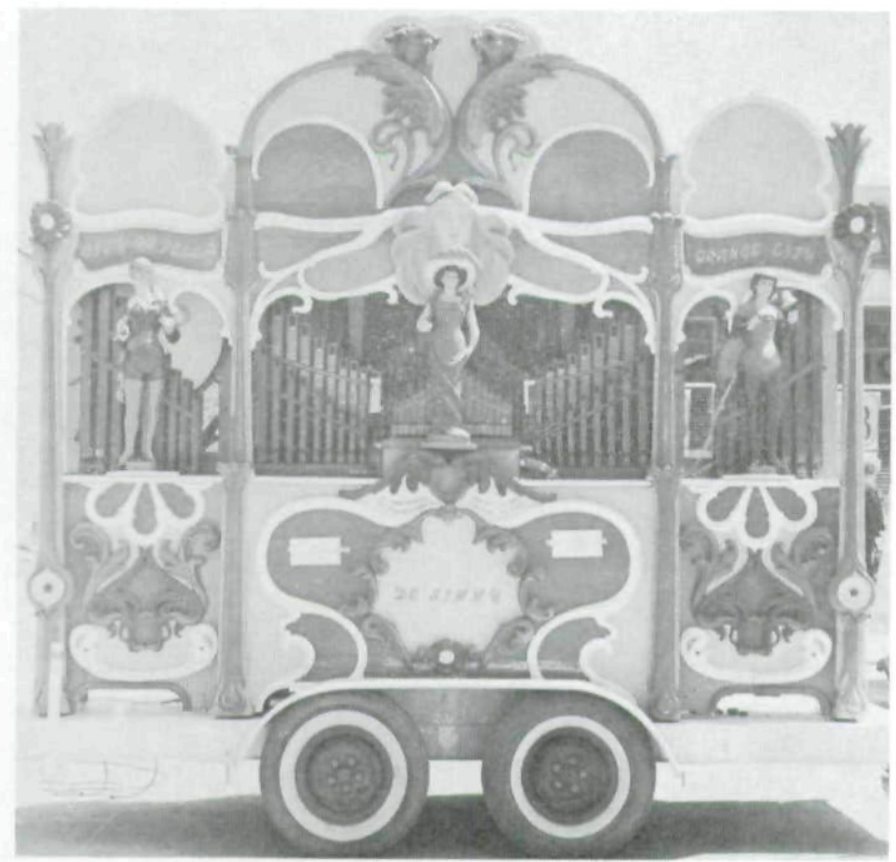

\section{Dutch Street Organ.}

It was in June, 1950, when the office of the secretary of the Orange City Chamber of Commerce received a long distance phone call from Philadelphia. At the eastern end of the line was Harry Van Pelt, professional actor from the Netherlands, who, with his wife, had just completed a three-day stand at the Orange City Tulip Festival. He had been engaged to furnish entertainment at the Netherlands Trade Fair in Philadelphia.

The motivation for his call to Orange City was the fact that a Dutch Street Organ had been imported for this Fair, 
but transportation costs had precluded its shipment back to the Netherlands. The officials had decided to dispose of it.

The Chamber secretary instantly recognized the potential advertising value of an acquisition of this type. There was only one other Street Organ in the United States. This would be the only one at that time in playing condition. A purchasing price was discussed; a hurried meeting of the Chamber and Tulip Festival officials was called, and a compromise figure was agreed upon. Within two hours of the first telephone call, the transaction had been completed and a check for the purchase price was on its way to Philadelphia.

The next obstacle to be hurdled was shipping arrangements and storage facilities in Philadelphia until such arrangements could proceed. With the aid of Harry Van Pelt, storage space was acquired.

Negotiations for transportation followed and after detailed investigation, it was decided to have the organ trucked to Orange City. Again difficulties were met relative to clearing with Interstate Commerce regulations. However, a solution was found and the organ arrived safely in Orange City.

The most common question concerning the Street Organ is "What are they used for in the Netherlands?"

Information gathered from reliable sources reveals that the manufacturers of the organs rent them to individuals who take them out into the streets of the city and furnish entertainment for the gathering public for whatever fee a "passing of the hat" will bring. In most cases the rental fee is a fixed sum on an hourly basis. In exceptional cases where the operator is known to be trustworthy the fee may be on a commission basis.

The operators who rent the organs are licensed by the City Government and all assigned definite routes and locations for a given day's appearance. In this way, with a half dozen or more organs making the rounds in a city, no one operator receives a monopoly on the spots or routes. In general an 
organ cannot stop more than 30 minutes. Each one is checked daily by policemen to ascertain that it is in its assigned area for that day.

Ordinarily three men accompany each organ. One is assigned to running the organ and the others "pass the hat." All three are needed to move the heavy instrument along the route to the various stopping places. Sometimes a horse is used to furnish the power.

Amusing tales accompany the varied reports relative to the street organ business. For instance, it is an accepted fact that the operator who has an attractive daughter accompanying him on his route will extract more coins from the public than others. Also, part of the entertainment is derived from the skill developed by the hat passers in catching small coins in the palms of their hands, tossed to them from fourth or fifth story windows. An interesting commercial aspect is revealed in the efforts of business men such as cafe operators, to induce the street organ operators to perform in front of their business places to attract prospective customers around their door.

Visitors to the Orange City Tulip Festival, on viewing the Dutch Street Organ, can thus picture themselves on the streets of a city in the Netherlands and seeing "A Little Bit of Holland." That is the main purpose behind the acquisition of this rare and romantic instrument.

\section{ACKNOWLEDGEMENTS}

Without a convenient and authentic source of information, a chronicle of this kind could not be compiled. We acknowledge the Festival Scrapbooks of my wife, Leona, as the source of facts and data, herewith presented in an extremely condensed form.

In orderly and chronological sequence the Scrapbooks contain hundreds of newspaper clippings of announcements and editorialized observations relating to the Festival. Chief among the contributions made by newspapers are the accounts of the Orange City Journal and the Sioux County Capital. 
Copyright of Annals of Iowa is the property of State of Iowa, by \& through the State Historical Society of Iowa and its content may not be copied or emailed to multiple sites or posted to a listserv without the copyright holder's express written permission. However, users may print, download, or email articles for individual use. 